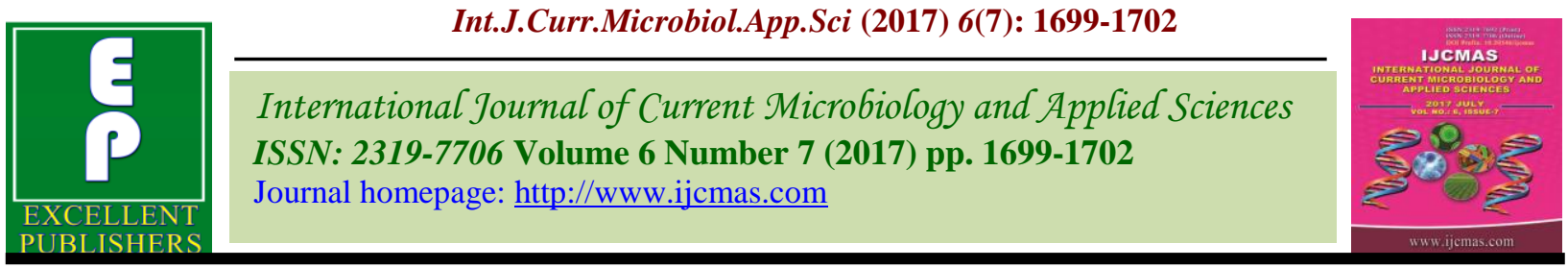

Original Research Article

https://doi.org/10.20546/ijcmas.2017.607.204

\title{
Constraints Associated with Adoption of Recommended Tuber Crops Production Technology among the Tribal Farmers of Bastar District Chhattisgarh, India
}

\author{
Lemesh Kumar Pandey ${ }^{*}$, R.S. Sengar, M.K. Chaturvedi and H.K. Patra \\ College of Agriculture and Research Station, Baikunthpur Korea, Chhattisgarh, India \\ *Corresponding author
}

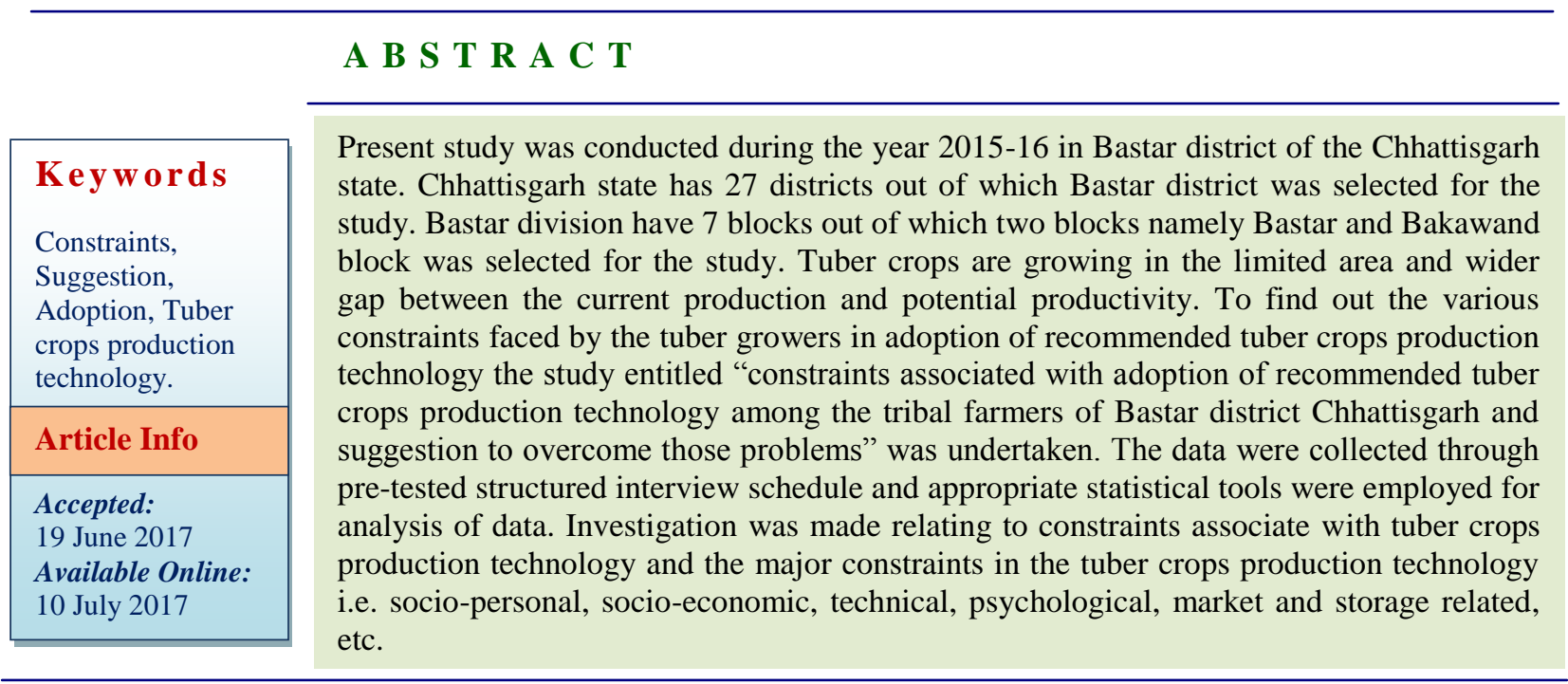

\section{Introduction}

Tuber crops are one of the most important staple crops in the world. It is consumed as raw or cooked; all over the world. It is the major staple foods in many parts of the tropics, being the source of most of the daily carbohydrate intake for large populations. On a global basis, approximately 55 percent of roots and tuber production is consumed as food; the remainder is used as planting material, as animal feed or in the production of starch, distilled spirits, alcohol and a range of other minor products. The patterns of utilization vary considerably among countries. In the developing countries, with the exception of China, Vietnam, Brazil and Paraguay, only small quantities (less than 20 percent) are fed to livestock and production is largely for on-farm food consumption. The relatively high costs of transport, processing and storage and the not inconsiderable time needed in preparation as food, frequently make roots and tuber crops less attractive to urban consumers. Bastar district is the full of surprises and have a huge cultural differences in this area. Rural people partake in a number of strategies, including agricultural intensification, migration and livelihood diversification, which enable them to attain a sustainable livelihood. Sustainable Livelihood approaches provide a framework for addressing poverty and vulnerability in both development and humanitarian contexts. They have emerged from the growing realization of the need to put the poor and all aspects of 
their lives and means of living at the centre of development and humanitarian work, while maintaining the sustainability of natural resources for present and future generations. Tuber crops are cultivated by the most of the farmers and they are facing various troubles whereas they are also economically poor and their production and productivity was also low. The present investigation help the government to make better policy towards the tuber crops production technology for enhancing the area production and productivity of tuber crops in this area.

\section{Materials and Methods}

The study was undertaken in the Bastar District of Chhattisgarh state. Out of seven blocks of Bastar division there are two blocks namely Bastar and Bakawand was selected purposively for the present study because the maximum area covers under the tuber crops in this area. From the each selected blocks there are 4 villages are selected randomly and fifteen respondents from each selected villages were selected. In this way total 120 respondents are considered as respondents. The data are collected through pre-tested structured interview schedule the data were analyzed by the appropriate statistical tools.

Present investigation has following objectives 1. To find the constraints faced by tuber growers 2 . To obtain suggestion to overcome those problems.

\section{Results and Discussion}

The constraints in tuber crops production are many and diversified. Again the constraint differs from individual to individual depending upon their social status, family, requirement, family obligation, cultural background and economic position.

Multiple responses were taken to ascertain the constraint faced by the tuber growers in adoption of recommended tuber crops production technology. Various constraints are presented in the table 1 which indicated that under the socio- personal constraints maximum numbers of respondents 52.50 per cent reported that lack of education followed by 40.00 per cent should less interest in tuber cultivation in adoption of recommended tuber crops production technology.

It has been observed in the table 1 that major constraints under socio economic category expressed by the respondents were unavailability of lack of seed and fertilizer well in time (70.83 per cent) difficulty in getting loan from national bank (65.00 per cent), small size of fields (46.66 per cent), and poor economic condition (35.00 per cent).

In case of technical constraints, the respondents reported lack of technical knowledge (41.66 per cent) as major constraints followed lack of recommended production technology in printed.

In case of psychological constraints the maximum respondents reported lack of risk bearing capacity ( 51.66 per cent), followed by agriculture activities done only for subsistence (48.33 per cent), lack of motivation (35.83 per cent).

Under the market and storage related constraints maximum no. of respondents (65.00 per cent) reported that the lack of minimum support price for tuber crops, (58.33 per cent), followed by lack of regulated market and more interference of middle man (46.66 per cent) were the major constraints faced by them. In addition to lack of storage facilities was also reported as a constraint by (38.33 per cent) of respondents in adoption of recommended tuber crops production technology. Constraints faced by the tuber growers in adoption of recommended tuber crops production technology. 
Table.1 Distribution of respondents according to constraints faced by them $(\mathrm{n}=120)$

\begin{tabular}{|c|c|c|c|}
\hline Particulars & Frequency* & Percentage & 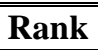 \\
\hline \multicolumn{4}{|l|}{ 1.Socio- personal constraints } \\
\hline Less interest in tuber cultivation & 48 & 40.00 & II \\
\hline Lack of education & 63 & 52.50 & I \\
\hline \multicolumn{4}{|l|}{ 2.Socio- economic constraints } \\
\hline Difficulty in getting loans from banks. & 78 & 65.00 & II \\
\hline Small size of fields & 56 & 46.66 & III \\
\hline Unavailability of Fertilizer and seed well in time. & 85 & 70.83 & I \\
\hline Poor economic condition. & 42 & 35.00 & $\mathrm{~V}$ \\
\hline \multicolumn{4}{|l|}{ 3.Technical constraints } \\
\hline Lack of technical knowledge & 50 & 41.66 & II \\
\hline Lack of recommended production technology for tuber & 72 & 60.00 & I \\
\hline \multicolumn{3}{|l|}{ 4.Psychological constraints } & \\
\hline Lack of risk bearing capacity & 62 & 51.66 & I \\
\hline Agriculture activities done only for subsistence. & 58 & 48.33 & I \\
\hline Lack of motivation. & 43 & 35.83 & III \\
\hline \multicolumn{4}{|l|}{ 5.Market and storage related constraints } \\
\hline Lack of storage facilities & 46 & 38.33 & IV \\
\hline Lack of regulated markets & 56 & 46.66 & III \\
\hline More interference of middleman & 70 & 58.33 & II \\
\hline Lack of minimum support price(MSP) for tuber crops & 78 & 65.00 & I \\
\hline \multicolumn{4}{|l|}{ 6.Transportation related constraints } \\
\hline Lack of transportation facilities & 63 & 52.50 & I \\
\hline \multicolumn{4}{|l|}{ 7.Communication related constraints } \\
\hline Lack of contact with extension agencies & 65 & 54.16 & I \\
\hline $\begin{array}{l}\text { Lack of training programmes related with tuber } \\
\text { crops production technology }\end{array}$ & 52 & 43.33 & II \\
\hline
\end{tabular}

*Data based on multiple responses

Table.2 Suggestions suggested by the tuber growers $(n=120)$

\begin{tabular}{|c|c|c|c|}
\hline Particulars & Frequency* & Percentage & "Rank \\
\hline $\begin{array}{l}\text { Govt. should be formulated better policies } \\
\text { for encouraging tuber crops. }\end{array}$ & 75 & 62.50 & III \\
\hline $\begin{array}{l}\text { Planting material should be available well } \\
\text { in time. }\end{array}$ & 63 & 52.50 & $\mathrm{~V}$ \\
\hline $\begin{array}{l}\text { Inputs i.e. Manure and fertilizers, } \\
\text { insecticide, pesticide etc. should be provided timely. }\end{array}$ & 78 & 65.00 & I \\
\hline $\begin{array}{l}\text { Extension agency should be organized } \\
\text { training on different aspect of tuber crops } \\
\text { production technology. }\end{array}$ & 45 & 37.50 & VIII \\
\hline $\begin{array}{l}\text { Processing industry should be established } \\
\text { by the Govt. }\end{array}$ & 60 & 50.00 & VI \\
\hline $\begin{array}{l}\text { Storage facilities should be provided by } \\
\text { govt. for long time markets. }\end{array}$ & 64 & 53.33 & IV \\
\hline $\begin{array}{l}\text { Marketing facility for tuber crops should } \\
\text { be regulated and middle man should be removed. }\end{array}$ & 76 & 63.33 & II \\
\hline $\begin{array}{l}\text { Procedure of taking loan and credit } \\
\text { facilities should be simple and easy. }\end{array}$ & 58 & 48.33 & VII \\
\hline
\end{tabular}

*Data based on multiple Responses 
In case of transportation related constraints, 52.50 per cent respondents reported that lack of transportation facilities found as major constraints in adoption of recommended tuber crops production technology.

In case of communicational related problem maximum respondents (54.16 per cent) reported, lack of contact with extension agencies followed by 43.33 per cent said that lack of training programmes related with tuber crops production technology.

Suggestions obtained from with regarding adoption of recommended tuber crop production technology

According to respondent suggestion data are categories and ranks were provided and sampling ranking technique was applied for the ranking. Results are mentions in table 2.

It is concluded from the table 2, that the maximum 62.50 per cent suggested that Govt. should be formulated better policies for tuber crops, followed by planting material should be provided well in time $(65.00$ per cent), extension agencies should be organized training programmes for the tuber crops production technology (37.50), processing industry should be developed by the Govt. (53.33 per cent), market should be regulated by the Govt. for tuber crops (63.33) and lastly procedure for providing loan should be simple and easy (48.33 per cent).

From the above findings it can be concluded that the maximum number of tuber growers were experienced various constraints, but major constraint was revealed that lack of education, unavailability of seed and fertilizer well in time, lack of recommended tuber crops production technology for tuber crops, lack of risk bearing ability, lack of minimum support price (MSP) for tuber crops, lack of transportation facilities and lack of contact with extension agencies and major suggestion offered by the tuber growers are; inputs like fertilizer, seed, insecticide, pesticides etc. should be available well in time, Marketing facility for tuber crops should be regulated and middle man should be removed, Govt. should be formulated better policies for encouraging tuber crops, Planting material should be available well in time etc. programmes are done for overcoming this constraints.

\section{References}

Kumbhare N.V. and Singh K. 2011, Adoption Behaviour and Constraints in Wheat and Paddy Production Technologies, Indian Res. J. Ext. Edu. 11 (3):215-218.

Singh Mamta, Dwivedi A.P., Mishra A., Singh R.P., Singh D., Singh S.R.K. and Prem Chand 2013. Adoption Level and Constraints of Soybean Production Technology in Sagar District of Madhya Pradesh. Journal of Community Mobilization and Sustainable Development Vol. 8(1):94-99.

Samantaray, S. K., Prusty, S., and Raj, R. K., 2009. Constraints in Vegetable ProductionExperiences of Tribal Vegetable Growers Indian Res. J. Ext. Edu. 9 (3):32-34

Mohanty, A.K., Lepch, B., and Kumar, Ashok. 2013. Constraints Analysis in Adoption of Vegetable Production Technologies for Livelihood Perspective of Tribal Farmers in North Sikkim. Indian Res. J. Ext. Edu., 13 (2):51-56

Singh, B.K., Rakesh E.S., Yadav, V.P.S., and Singh D.K., 2010. Adoption of Commercial Cut Flower Production Technology in Meerut. Indian Res. J. Ext. Edu., 10 (1):5053

\section{How to cite this article:}

Lemesh Kumar Pandey, R.S. Sengar, M.K. Chaturvedi and Patra, H.K. 2017. Constraints Associated with Adoption of Recommended Tuber Crops Production Technology among the Tribal Farmers of Bastar District Chhattisgarh, India. Int.J.Curr.Microbiol.App.Sci. 6(7): 1699-1702.

doi: https://doi.org/10.20546/ijcmas.2017.607.204 